\title{
An Assessment of Public Private Partnerships for Housing Projects in Bauchi State, North Eastern Nigeria
}

\author{
Yakubu Nehemiah Sanda \\ Department of Estate Management \\ Faculty of Environmental Sciences \\ University of Jos \\ Nigeria \\ E-mail: sanda_yakubu@yahoo.com \\ Natalia A. Anigbogu \\ Department of Building \\ Faculty of Environmental Sciences \\ University of Jos \\ Nigeria \\ E-mail: natashaanigbogu@yahoo.com \\ Mallo Maren Daniel \\ Department of Estate Management \\ Faculty of Environmental Sciences \\ University of Jos \\ Nigeria
}

Received: September 29, 2016 Accepted: November 1, 2016 Published: November 21, 2016 doi:10.5296/ijrd.v4i1.9933 URL: http://dx.doi.org/10.5296/ijrd.v4i1.9933

\begin{abstract}
Public Private Partnership (PPP) has gained wide acceptance as a strategy for housing provision in many countries. However, the level of success varies from one country to the other due to economic, political and cultural variations. This study examines PPP in housing in Bauchi State in Nigeria using Unity Housing Estate as a case study with the view to
\end{abstract}


examine its performance and to suggest possible measures for improving the effectiveness of the concept. Methods of data collection used were semi-structured interviews and direct observation. Interviews responses were tape-recorded in addition to note taking which were subsequently transcribed and validated. The model of PPP used in the area was the Design-Build-Finance arrangement in which the private party takes the responsibilities for the design, finance and construction of the housing units. The houses were far beyond the affordability level of the target beneficiaries. Some of the challenges depicted were lack of political will, corruption among government agents and private sector developers, insincerity of contacting parties and unavailability of development fund. The study suggests among others, attitudinal change among stakeholders to ensure the success of PPP housing, the need to establish and empower relevant institutions that will help in fighting corruption.

Keywords: Public, Private, Partnership, Housing, Projects, Nigeria

\section{Background to the Study}

In recent years, the increasing demand for housing and budgetary constraints in several developed and developing countries have led governments to seek new ways of housing provision. An option that has been adopted by many governments is establishing partnership with the private sector usually referred to as Public Private Partnership (PPP). The principal reason for adopting PPP for housing provision is that, the approach offer greater value for money when compared with the traditional procurement system. Since the adoption of PPP in the housing sector in the early 1990s, almost all countries around the world have witnessed some form of PPP investment in the provision of housing and urban infrastructure (UN-Habitat, 2011). The concept has been practiced in housing in countries such as USA, UK, Canada, Malaysia, South Africa, Egypt, France, China, India, and Australia. Although the level of success in terms of housing units developed through this initiative may vary from one country to the other due to the different economic, political and cultural circumstances, PPP has been successful in many countries (Al-Shareem, Yusof, Roosli, \& Abdullahi, 2004)

Nigeria is one of the countries that have adopted PPP at various levels of government (Federal, State and Local Government) across the country. The idea of embracing PPP was to shift away from a state-led and bureaucratic management approach to a market-oriented environment whereby public and private solutions would complement each other (Daniel, 2014). In such arrangements, the public institutions are to serve as brokers networking private sector institutions, non-governmental organisations (NGOs) and community based organisations (CBOs) to perform the role of financing the supply of new housing on behalf of the public sector so as to reduce the Nigerian housing deficit. In addition, the decentralization of decision making at the local level as a result of co-opting the private sectors is expected to promote good governance by way of accountability, transparency and efficiency in the provision of housing. In theory therefore, PPP was meant to enhance government capacity to develop integrated solutions, facilitate creative and innovative approaches that could reduce the cost and time spent to implement projects, transfer certain risks to the private partner, facilitates larger productivity and attract more sophisticated bidders to projects while at the same time providing an avenue to access better skills expertise and technology (Li \& 
Akintoye, 2003) with the view of improving the delivery of housing in Nigeria.

Despite the adoption of PPP in housing, the issue of housing in both quantitative and qualitative terms still remains intractable. Reports from various parts of the country suggest that, PPP has not been as successful as earlier me of the PPP housing projects were successfully executed, some failed (Ibem and Aduwo, 2012; Ahmed, Moohammad and Abubakar, 2010; Abdullahi and Abdul-Aziz, 2010). The success of any PPP arrangement is a function of the economic, political, social and cultural conditions under which the projects are undertaken (Carbonara, Costantino, Pellegrino and Scincalepore, 2011). The variations in these factors coupled with the dearth of research on PPP in Bauchi motivated this study in order to evaluate its application in housing in Bauchi state with the view to examine its performance and to suggest possible measures for improving the efficiency of the strategy for effective housing provision. To achieve this aim, it is imperative for this study to provide answers to the following questions: How are the PPP contracts housing projects structured in the study area; How affordable are the housing units constructed using PPP in the study area; How satisfied are the households with the housing units and infrastructure; and How can the challenges bedeviling PPP implementation in housing in the study area be overcome? The objectives of the study include:

i To examine the structure of PPP used in housing provision in the study area.

ii. To determine the affordability of the housing units constructed using PPP in the study area.

iii. To assess the level of satisfaction of households with the housing units

iv. To identify the challenges bedeviling the implementation of PPP in housing in the study area.

\section{Literature Review}

PPP has been defined differently by different researchers such that, the concept has no consensus definitions. Consequently, different researchers have offered different definitions. The Canadian Council for Public Private Partnership (CCPPP) (2005) defines PPP as a cooperative venture between the public and private sectors, built on the expertise of each partner that best meets clearly defined public needs through the appropriate allocation of resources, risk and rewards. PPP is any contractual arrangement between a public entity and a private sector party, with the clear agreement on shared objectives for the provision of public infrastructure and services traditionally provided by the public sector (Republic of Ghana, 2011). In such arrangements, the public sector party performs part or all of a government's service delivery functions and assumes associated risks for a significant period of time in return for benefits/financial remuneration according to predetermined performance criteria. Harmonising these definitions, PPP can be regarded as any long-term, contractually regulated cooperation between the public and private sector for the efficient fulfillment of public tasks in combining the necessary resources of the partners and distributing existing project risks appropriately according to the risk management competence of the project partners. 
Most definitions of PPP simply present the concept as a contractual arrangement between the public sector and a private entity but in reality, it is a complex network of relationships involving multiple parties working within the confine of a contract.. Relationships in PPP arrangements can best be understood or explained by Game Theory. This theory was propounded by John von Neumann and Oskar Morgenstern in 1944 as mathematical model for explaining conflict and cooperation between intelligent rational decision makers. A game consists of number of players, set of strategies for each player, and a payoff that quantitatively describes the outcome in terms of the amount of gain or loss made by each player (Zou and Kumarasawamy, 2009). For instance, profitability describes the payoff for executing a project in line with the provisions specified in the contract documents. There are basically two types of games: cooperative and non cooperative. The players in cooperative games (usually referred to as non-zero sum games) are bound by agreements and the interests of the players are neither completely opposite nor completely coherent (Barron, 2007). This game is bounded by rationality principle where each player tries to maximize one's payoff and taking into account the fact that the opponent is also trying to maximize his payoff. However, following one's rationality breeds conflict between self interest and collective interests. The best solutions in non-zero games are the Nash Equilibrium where no player has anything to gain by changing only his or her own strategy(self interest) since achieving collective interests is the ultimate goal of the game (Kargol and Sokol, 2007). PPP can be likened to cooperative games where the players (public agencies and private organisations) are bound by agreements (Memorandum of Understanding) specifying clearly methods of operation as well as the responsibilities and benefits of the contracts. Though there is often conflict of interest between contracting parties (players) which may result to opportunistic behaviours such as moral hazard and hidden intentions, the possibility of cooperation to achieve common goals cannot be ruled out. Each party in PPP tries to maximize its interests at the same time bearing in mind that the other party is also trying to maximize his interest. The arrangements therefore work best when it is structured such that no party gains by performing outside the agreement contained in the MoU.

The PPP models used in housing delivery in Nigeria share similar features with what is obtainable in Australia, India, Malaysia and South Korea (Choe, 2002; Sepgunta, 2005; Abdul-Aziz and Kassim, 2011). In typical PPP arrangement for housing development in Nigeria, the private sector assumes the responsibility for design, finance (all or part of it) and construction of the housing units. The public sector on the other hand would normally contribute the land, counterpart funding where necessary, determine the housing typology and the selling price. However, these responsibilities may vary from one place to another and even among projects depending on the contract arrangement. Funding of PPP housing in Nigeria is basically through loans from Federal Mortgage Bank of Nigeria and/ or other sources such as Commercial Banks, Insurance Companies etc. The framework for undertaking PPP housing provision schemes in Nigeria is based on the negotiated roles for each partner organisation as indicated in the MoU and Development Lease Agreement for each housing scheme.

Despite officially embracing PPP in housing delivery by the government almost two decades 
ago, the achievements recorded are far below the expectations of Nigerians. Some of the projects signed were never implemented and some few that were started were not completed. Although some of the projects could be regarded as successful, not all met the standards set for affordable housing. This dismal performance of PPP in the area of housing delivery may not be unconnected with the constraints bedeviling the implementation of the concept in Nigeria. The major constraints to effective implementation of PPP in housing include land accessibility and affordability, insincerity among partners, corruption, funding constraints, regulatory constraints, lack of political will, lack of experience in PPP, engaging projects that do not suit PPP, lack of basic infrastructure, selection of wrong partner and high cost of social amenities, constraints in the supply of building materials, prevailing condition in the building industry, inability of financial institutions to carry out thorough and rigorous analysis of projects and assess the technical ability of operators, lack of awareness among stakeholders, organizational constraints, lack of motivation for private sector investors, non-adherence to planning standards, challenges of poverty and lack of proper monitoring among others (Ibem, 2010; Abdullahi and Aziz, 2010, Dahiru, Abdul'azeez and Bala, 2013, Onuorah, 2014).

These challenges cut across all tiers of governance and need to be properly assessed and addressed in order to improve housing provision through PPP. This study therefore is informed by the need to examine the performance of this initiative in housing provision. Bauchi State being one of the pioneer States to embrace PPP in housing was selected for the study with view to determine the major challenges bedeviling its effective implementation and to proffer solutions towards improving the effectiveness of the concept.

\section{Study Area and Method}

The study area is the Unity Housing Estate, located along Bauchi - Jos Road, $15 \mathrm{Km}$ from Bauchi Town. The Project was initiated in 2009 by the then Governor, Mallam Isa Yuguda which was a typical PPP project involving the Bauchi State government and a private company Terraquest Development Company Limited. The arrangement was to deliver 1000 housing units of low cost housing for civil servants in three phases. While the Phase 1 has been completed, the second and third phases are yet to begin. The first phase which is the subject of this study was to construct 571 units of 3 bedrooms detached and 2 bedrooms. This phase was to be constructed in three stages: The first stage which comprises of 288 housing units has been completed and commissioned. Stage two which has 171 housing units is at the finishing stage; and the third stage which comprises of 112 housing units is at the foundation /DPC level. This estate is one of the pioneer PPP projects in Bauchi state. A preliminary survey of the study area reveals that, though some of the housing units were completed and occupied, the project did not achieved the degree of success earlier envisaged and the basic housing infrastructure were not adequately provided. This presents an ideal study area in order to examine the practice of PPP in housing in Bauchi state.

The housing units constitute the subject of study while the study population consists of the contracting parties (representatives of the government and private sector company) involved in the implementation of the project and the civil servants who are the direct beneficiaries. Considering the type of research questions posed, the study followed qualitative approach 


\section{Mll Macrothink}

(Yin, 2006). The method adopted in this research was the case study which allows the researcher studying a phenomenon within its context. The difficulty in identifying participants in the project coupled with the need to use expert opinions necessitated the use of non-probability purposive and snowballing (network sampling) methods to select the sample for the study. Purposive sampling technique enables researchers to select cases that will best answer the research questions and to meet the objectives of the study. It is considered appropriate for selecting a sample when the researcher intends to select participants who have experience about central phenomenon or key concept being explored while snowballing is commonly used when it is difficult to identify members of the desired population. In snowballing, the researcher makes contact with one or two cases, ask these cases to identify further cases, ask these new cases to identify further new cases and so on until either no new cases are given or the sample is as large as is manageable (Cresswell and Clark, 2007; Saunders, Lewis and Thornhill, 2009).

Methods of data collection adopted in this study were semi-structured interview and physical observation physical phenomena (housing units). Interviews were used in research to explore views, experiences, believes and/ or motivations of individuals on specific matters. Semi-structured interview was considered appropriate because it enables spontaneous probing to uncover deeper issues of concern which may not readily surface by other methods (Fowler and Walsh, 1999). On the other hand, physical observation helps in description of events and behaviours in the social setting used to obtain information on case studies allowing the investigator to carry out site visits to gather data for the study (Marshall and Rossman, 1995). Individuals selected for interview directly or indirectly participated in the development of the estate or were beneficiaries of the housing project. A total number of 10 respondents were interviewed and the breakdown is presented in Table 1. Two representatives each were interviewed from the Public Sector (Ag. Deputy Director, Housing and Project Site Engineer) and Private Sector (Chief Estate Manager and Mortgage Officer). Three representatives each from the occupants of 3 bedrooms dethatched and 2 bedrooms housing typology were also interviewed. From the Table 1 it is evident that the interviewees are the real information gatekeepers because of either their positions in their respective organizations or their direct connection with the study area. Consequently, whatever information they supplied was considered to be reliable for the purpose of this study. An interview guide was designed consisting of a set of open questions, reflecting the objectives of the research and the interview was tailored to suit the interviewees' particular involvement in the housing project. In addition to note taking, the interviews were tape-recorded, transcribed and validated. The breakdown of the interviewee and their respective codes are shown in Table 1. 
Table 1. Interview respondents

Interview respondents

Represented alphabets

Representative of Bauchi State Government (Ag. Deputy ADH

Director, Housing)

Representative of Bauchi State Government (Project Site PSE Engineer)

Representative of , Terraquest Development Company Ltd (Chief ESM

Estate Manager)

Representative of Terraquest Development Company Ltd MGO (Mortgage Officer)

3 representatives of housing beneficiaries (3 bedrooms 3BR categories)

3 representatives of housing beneficiaries (2 bedrooms 2BR categories)

Source: Authors' compilation, 2016.

\section{Discussion and Findings of Empirical Study Conducted}

\subsection{Structure of PPP Arrangement for the Project under Study}

There are various PPP models that can be adopted in delivering public services and each presents the contracting parties with certain benefits as well as disadvantages. These structures or models of PPP are usually defined by the responsibilities assumed by the contracting parties. This section therefore examines the responsibilities of the parties involved in this housing project in order to determine the model adopted for this particular project. The question asked in connection to this is: how were the responsibilities shared among the contracting parties in this particular arrangement? The State Government officials $(\mathrm{ADH})$ state that:

"...in the Memorandum of Understanding (MoU) signed by Bauchi State government and the Private Sector (Terraquest Development Company Limited), the government was responsible for providing the land including payment for compensation, housing infrastructure and Bank guarantee (serving as guarantor) while the private company was responsible for providing the design, financing and actual construction of the project. Upon completion, the government would assume ownership of the housing units for onward allocation to the beneficiaries" 
"...the developer provided the design; the ministry went through it and made some amendments based on the culture and tradition of the state" (PSE).

In a similar manner the private company's Estate Manager (ESM) said:

"...the company was responsible for providing the project design, development finance and physical construction of the project. The government was to provide the land, pay for the compensation, provides bank guarantee and infrastructure"

This arrangement depicts a typical Design-Build-Finance (DBF) model which saddles the private sector with the responsibility for designing, financing and construction of the project. The responsibility of the private partner ends at the completion of the development while the public agency retains ownership and takes charge of the project operation. This approach is most desirable where the government requires new facility or service but may not have the financial backing to execute the project (Canadian Council for Public Private Partnerships (CCPPP, 2011). Furthermore, since the private funds can be used for up-front costs, the likelihood of time lost due to pre-construction fundraising delays is reduced, and in turn, the design and construction process may be expedited (National Council for Public Private Partnerships (NCPPP), 2012). The Bauchi State Government adopted this model due to lack of development fund to finance the project as posited by the Ag Deputy Director, Housing in the State Ministry of Lands and Housing (ADH). On the rational for adopting the DBF arrangement by the state government, $\mathrm{ADH}$ said:

"...the government preferred this arrangement because at that time there was no money to finance the project; the government therefore saw it as an opportunity for getting the project done since the project would be financed by the private company thereby freeing government little available funds for use in other sectors"

In regards to observing the agreements as contained in the $\mathrm{MoU}$, a representatives of the government (ADH AND PSE) and the private company (ESM AND MGO) affirmed, that the Bauchi State Government did not fulfill its obligations as specified. The government neither paid the land compensation nor provided the infrastructure as earlier agreed. The Project Site Engineer (PSE) stressed that:

"...the State Government actually provided the land as agreed but did not pay for the compensation which was $\$ 23$ million; rather it pleaded with the private company (Terraquest Development Company Ltd) to pay the compensation on the understanding that the Government will pay back which the company did but was never refunded"

The Ag Deputy Director, Housing confirmed this statement and said:

“..... the government failed to pay for compensation as earlier agreed upon; in fact the only money the government released to Terraquest was 10 million only during the visit of the Federal Minister for Housing to Bauchijust for the company to allow government lay claim to the project in order to permit the Minister to commission it".

This shows lack of commitment on the part of the State Government. In a similar study, absence of favourable micro-economic level, political and socio-cultural climate were also 
reported as the major challenges to adopting PPP in housing provision in Bauchi State (Ayodele and Dominion, 2015). Lack of commitment among parties to PPP contracts had been reported earlier as a major challenge to adopting PPP in housing in Abuja (Abdullahi and Abdul-Aziz, 2012) Onuorah (2014) also reported that, lack of commitment has especially political will power has been one of the major challenges to implementing PPP in housing provision. This statement also shows lack of credibility on the part of government which is necessary for attracting private investment. A participating government must demonstrate credibility as a responsive and responsible party in all contractual relationships (Yang, Hou and Wang, 2013).

\subsection{Affordability of the Housing Units Constructed}

A key component of a successful housing delivery programme is the affordability of such housing units to the target consumers. Housing is affordable only when it does not cost more than $30 \%$ of the income of the occupant household (Andrew, 1998). Housing affordability therefore is a function of cost of housing and household income. This section therefore attempts to determine the affordability of the housing units constructed in the study area by relating household income to the housing prices. The question asked in connection with housing prices is: what is the sales price of the housing units? There was unanimous response among the representatives of key actors (government agency and private sector), that the houses were being sold at prices higher than initially agreed. The Estate Manager representing Terraquest Development Company Limited (ESM) said:

“...the housing units were to be constructed at the cost of $\$ 3.4$ million for 2 bedrooms and \#4.95 million for 3 bedrooms but because the government could not provide funds for infrastructure the private sector had to borrow separate fund to finance infrastructure. As a consequence; the prices increased from $\$ 3.4$ million to $\$ 4.2$ million (2 bedrooms semi-detached) and $\$ 4.95$ million to $\$ 5.9$ million (3 bedrooms detached) to cover for the amount expended in providing infrastructure".

In a similar vein, the $\mathrm{ADH}$, said that:

"...the State Government could not provide the infrastructure as earlier agreed; the private company did. The government was not able to pay the amount expended; therefore the company was advised to factor the cost of infrastructure into the housing cost which then raised the prices from $\$ 3.4$ million to $\$ 4.2$ million (2 bedrooms semi-detached) and $\$ 4.95$ million to $\$ 5.9$ million for 3 bedrooms ".

It can be inferred from these statements that upon completion of the housing units, the prices increased with about $23.5 \%$ and $19 \%$ for 2 bedrooms semi-detached and 3 bedrooms detached respectively. In addition, the government lost the control of the project due to her inability to discharge her responsibilities as contained in the contract agreement. Consequently, the earlier arrangement that beneficiaries would pay $10 \%$ and $20 \%$ down payment (for 2 bedrooms semi-detached and 3 bedrooms detached respectively) while the FMBN pays the remaining balance which would be recoup from households salaries through installment deduction could not hold (ADH \& MGO). The target group could not afford the 
outright payment due to low salary structure; consequently the housing units remained voids for a period and some of the houses were been vandalized. As a result, the State Government advised the private developer to seek for buyers and dispose of the housing units.

The private company therefore devised four means of disposing the housing units open to the general public. These include: 1) payment of $10 \%$ and $20 \%$ of the total housing cost as deposit for 2 bedrooms 3 bedrooms respectively; 2) Renting (between $\$ 60,000$ - $\$ 70,000$ per annum for 2 bedrooms semi-detached and $\$ 80,000$ - $\$ 100,000$ per annum for 3 bedrooms detached); and 3) Outright sale for those that can afford it. The cost of a 2 bedroom semi-detached housing was $\$ 4.2$ million to be paid over a period of 30 years which amounts to $\$ 140,000$ per annum; $30 \%$ of the beneficiary's annual income who earns $\$ 420,000$ would amounts to $\$ 126,000$ which is far less than the amount required as annual repayment for the housing. During the interviews, representatives of the beneficiaries unanimously agreed, that the prices of the housing units were unaffordable considering the income level of civil servants in the study area. These therefore showed that the housing units constructed under this arrangement fails the affordability test. Ibem and Aduwo (2012) had reported in a similar study conducted in Ogun State, Nigeria, that the cost of housing units constructed through PPP are much more higher than those constructed through non-PPP arrangements. In addition to the cost of housing units, the beneficiaries are often required to provide guarantors and fulfill other conditions to qualify for mortgage loans which are always difficult for them to meet up. One of the reasons for adopting PPP for housing provision as against the direct approach is to make housing more affordable to the target group. However, the study suggests that, the housing units provided are not affordable to most low-income people.

\subsection{Household's Level of Satisfaction with Housing Units and Infrastructure}

Housing has grown beyond mere shelter and physical dwelling unit to include all the auxiliary services and community facilities, which are necessary for human well-being. Adequate housing takes into account the entire neighbourhood, consumer's desirability, the physical setting, facilities that ingress into and outflow from the community and must be a home in an environment which the occupant would like to live in (Augustine, 2005). It becomes imperative therefore to determine occupants level of satisfaction in relation to the building envelop and housing infrastructure. The question asked in connection to this is: how satisfied were they with the building structure and housing infrastructure? Concerning the building structure, the entire household representative revealed their dissatisfaction with facilities of the buildings such as sizes of the kitchen/dinning, bathrooms, toilets as well as the standard of construction. However, opinions vary between the occupants of the two types of housing ( 2 Bedrooms semi-detached units and the 3 bedrooms detached units) concerning the sizes of the rooms and kitchens. For instance while one representative of the two bedroom occupants (2BR (2)) said he was satisfied with the sizes of the bedrooms and kitchen, a representative of the three bedroom occupants (3BR (3)) reported that the bedrooms were too small likewise the kitchens and the dinning; kitchens in 2 bedrooms are almost of equal sizes to our bedrooms.

Similarly, during the physical survey, it was observed, that the building were poorly finished. 
In spite of the fact that the estate had just been completed, most buildings showed signs of damp penetration which is usually a sign of lack of damp proof course (DPC)/ membrane (DPM), visible cracks were observed, discoloured ceiling boards which was an indication of leaking roofs and peeling of paints. One of the respondents confirmed this statement and said:

"...... we had to spend between $\$ 20,000$ - N30,000 before we could move in because the buildings were poorly finished; some of the roofs leak during rainy season; I had to change all the locks in this house because the initial ones were faulty; I also re-painted the whole building because the paints had started peeling; You can see the inspection chambers has no vent pipes therefore it is very irritating to live inside the bedroom close to the toilet because of foul odour"

It was also reported that the private company did not follow the specifications as provided in the design. For instance, on the building drawings for 3 bedrooms, the size of master's bedroom is $11 \mathrm{~m}^{2}$ while the other rooms measure $8.4 \mathrm{~m}^{2}$ each. However, the master's bedrooms as built were less than the measurements on the drawings. Similarly, the size of the dining as provided in the drawing is $5.44 \mathrm{~m}^{2}$ while in the on the building it was far less. In typical PPP arrangements, contracting parties often engage in shoddy practice in order to maximize their payoffs which can only be curtailed if there are checks and balances such as adequate supervision and effective regulatory framework. However, the project was not adequately supervised by the State Government as contained in the MoU because the State Government lost control of the Project due its inability to honour its part of the agreement by paying the land compensation. This was confirmed by the representatives of the Bauchi State Government (ADH and PSE) that:

".....the government lost total control of the project and therefore could not insist that the private company follow the project specifications as provided in the contract document. Consequence, the private company did not follow the agreed specification especially as it relates to material selection and use".

Similarly, the representative of the private company (MGO) said:

“....because the State Government negates in her promises, our company was doing it all alone; the company ran short of funds because the funds were not coming from the FMBN; This was so because, the company used part of the development funds to pay land compensation and so could not develop the buildings to the level that will qualify her to receive the next installment from the FMBN"

In connection with the housing environment, all the respondents registered their high satisfaction with the quality of the road network, water supply, electricity and drainage system within the estate. However, the respondents expressed high dissatisfaction with unavailability of recreational facilities, absence of security outpost, waste disposal/ management facilities, lack of health care facilities and general maintenance arrangements. For instance, representatives of households occupying the 2 bedrooms semi-detached (2BR 1 \& 3) units said:

“...every household pays 1,000 service charge and 1,500monthly for housing 
maintenance and waste clearance but nothing is been done by the company because we maintain the houses with our resources and also take the responsibility for waste disposal"

The representative of the private company (ESM) confirmed that such amounts have been collected from the occupants in order to ensure proper management and maintenance of the estate. However, when questioned on how effective are these strategies, he responded "the company is trying its best and hopes to improve with time". It can be inferred the foregoing discussions, that the housing units, infrastructure as well as maintenance arrangement did not meet up with the requirements of the occupants. In most housing projects in developing countries such as Nigeria, housing beneficiaries are been involved in the production and delivery process (Adeogun and Taiwo, 2011). In PPP arrangements, private enterprises often pursue self-interest by focusing on profit maximization thereby harming consumer interests by embezzling public funds, delivering low service/ asset quality than specified, charge more money than they are suppose and cut back on maintenance expenses as long as they can get away with it (Mu, de Jong and Heuvelhof, 2010).

\subsection{Challenges to effective implementation of PPP in housing}

Public Private Partnership can be an important tool for delivering public housing; however like other contractual arrangements, its implementation is not without challenges. This section examines the challenges encountered in the implementation of the project under study. The respondents were asked to state the major impediments to effective implementation of the PPP arrangement between the Bauchi State Government and Terraquest Development Company. The four respondents (ESM, MGO, ADH and PSE) single out lack of political will as the major challenge encountered in the implementation of this project. For instance the Project Site Engineer said:

".....the main problem that affected the success of this project was lack of commitment from the government because, the government did not give the private company the needed cooperation; aside the provision of land, there was no further commitment on the part of the government which led the private company to drag the government to the court"

Similarly, the Estate Manager (ESM) said:

".....the government did not show much commitment to ensure the success of this project; as a the company had to drag the Bauchi State Government to court; right now the case between the Government and the company over this project is before the court".

Lack of strong political will has been reported in other studies as one of the major setbacks to successful PPP housing projects (Abdullahi and Aziz, 2011; Onuorah, 2014). Without an overall political environment favouring both private for-profit and not-for profit activities no real partnership can be established (Pessoa, 2006). Failure of the government to pay for compensation seriously undermined the success of the housing project; as a consequence, the private company took the Bauchi State Government to court to seek for redress. If a party to PPP fails to abide by the terms and conditions of the contract, there is likelihood of dispute which may lead to court litigation (Iboh, Adindu and Oyoh, 2013). Other challenges reported include lack of continuity in government, misplacement of priorities on the part of the 
government, lack of adequate supervision, pursue of self interest on the part of the private sector, inadequate planning and absence of local/internal finance (ADH and PSE), corrupt practices among the contacting parties, lack of experience on development of PPP, weak demand for the project and lack of adequate legal structure to protect the private investor (MGO). These findings also confirm the report of other studies on PPP. For instance, Abdullahi and Aziz (2011) had earlier reported that, failure in PPP housing in Nigeria can be linked to pervasive nature of corruption among private partners and government agents; selfishness and disregard to standing regulatory rules as well as constituted authorities and institution by the participating organized private sector, non-availability of low-interest fund from both the government and financial institutions which severely constraints participation of the low income in the housing market.

\section{Conclusion}

This paper examines the adoption of PPP in housing in Bauchi State North Eastern Nigeria. The adoption of PPP has not made significant impact in reducing the housing deficit in the study area. The dismal performance of the initiative is attributable partly to planning and partly to the implementation of PPP arrangements. In terms of planning, adequate attention is not paid to the financial details of the private sectors to ensure that the project will be successfully implemented should the sponsors become bankrupt. In relating to implementation, there are no adequate measures in place to ensure that contracting parties adhere to the provisions of the contracts. In other words, there are no adequate or specified penalties to deter the contracting parties from defaulting in fulfilling their contractual obligations. In the case study area lack of political will, inadequate regulatory framework guiding PPP implementation, corruption among government agents and the private sectors were some of the identified challenges. PPP housing projects are usually targeted at the low income earners but many of the target group cannot afford the housing units. The study therefore suggested that some form of subsidy is required either in form of initial grant by the government or some form of mortgage arrangements where the government pays part of the housing cost. The level of satisfaction of the beneficiaries with respect to the building structure and housing infrastructure is low. This is because the contracting parties failed to observe their obligations as specified in the contractual agreement. When parties to a contract pursue personal interest instead of collective interest it affects the achievement as postulated in game theory that no player gains by changing only his or her own strategy. The study suggests that adequate and enforceable regulatory framework for effective implementation of PPP arrangement in the study area. There is the need to establish and empower relevant institutions that will help in fighting corruption among stakeholders, the need to increase the supply of low-interest fund to developers as well as home buyers in order to boost their capacity for participation in the housing market.

Although some of the housing units have been completed, and commissioned, much needs to be done if PPP is to make the desired success. It may be too early to conclude, that PPP in housing in Bauchi has failed given the short time it has been in practice in the state. However it is obvious from this study that, addressing the challenges identified in this study will boost the success of PPP in housing in the study area. Even though the project was not as successful 
as envisaged, PPP arrangements should be upheld in the provision of public housing in subsequent housing projects. With increased commitment from the government, PPP can go a long way in delivering the desired housing in the study area.

\section{References}

Abdullahi, B. C., \& Abd-Aziz, W. (2010). Nigeria's Housing Policy and Public-Private Partnership (PPP) Strategy: Reflections on Achieving Home Ownership for Low-Income in Group in Abuja, Nigeria. Urban Dynamics and Housing Change. Retrieved from http://bmdynamics.com/issue_pdf/bmd110384-\%2060-68

Abdullahi, B. C., \& Abd Aziz, W. A. (2011). Pragmatic Housing Policy in the Quest for Low-Income Group Housing Delivery in Malaysia. Journal of Design and Built Environment, $8,21-38$.

Abdul-Aziz, A. R., \& Kassim, P. S. J. (2011). Objectives, Success and Failure Factors of Housing Public-Private Partnerships in Malaysia. Habitat International, 35, 150-157.

Adeogun, O. B., \& Taiwo, A. A. (2011). Housing Delivery through Public-Private Partnership in Nigeria and the Case for Beneficiaries' Involvement. Journal of Construction Project management and Innovation. 1(2), 63-79.

Ahmed, M. B., Moohammad, Y. A., \& Abubakar, S. U.(2010). Assessing Delievry in Nasarawa State Through Public Private Partnership: Focus on the 500 Housing Units in Lafiya. Proceedings of the International Conference of the School of Environmental Technonology, Federal University of Technology, Akure, Nigeria. $25^{\text {th }}-27^{\text {th }}$ October. PP 358-365.

Al-Shareem, K. M., Yusof, N., Roosli, R. B., \& Abdullah, A. (2004). Public Private Partnership as a Housing Delivery for Affordable Housing Development in Yemen. Business Management Dynamics, 3(8).

Andrew, O. N. (1998). Trends in the supply of affordable housing meeting American's housing needs (AAHD). A habitat II follow-up project.

Augustine, S. T. (2005). Housing conditions in Kakuri District, Kaduna. Department of Geography and Planning, University of Jos.

Ayodele, I. O., \& Dominion, A. (2015). Public Private Partnership as a Veritable Means of Housing Provision in Bauchi, Nigeria. International Journal of Social Sciences and Humanities Research, 3(1), 415-421.

Barron, E.N. (2007). Game Theory: An Introduction. A John Wiley and Sons, Inc., Publication.

Canadian Council for Public Private partnership. (2011). Public private Patnerships: A Guide for Municipalities. Canada.

Carbonara, N., Costantino, N., Pellegrino, R., \& Sciancalepore, F. (2011). Italian PPP Applications: A Theoritical Framework. Public Private Partnership in Transport: Trends and 
Theory-Research Roadmap.

Choe, S. C. (2002). The Promises and Pitfalls of Public Private Partnerships in Korea. International Social Science Journal, 54(172), 253-260.

Creswell, J. W. (2007). Qualitative inquiry \& research design: choosing among five approaches (2nd ed.). California: Sage Publications Inc.

Dahiru, D., Abdul'Azeez, A. D., \& Bala, K. (2013). Study of Measures of enhancing Public Private Partnership towards Infrastructural Development in Nigeria. Sustainable Building Conference. Coventry University.

Daniel, M. M. (2014). Enabling Access to Housing in Jos, Nigeria: Implementation and the New Bureaucrats.

Fowler, A., \& Walsh, M. (1999). Conflicting Perceptions of Success in an Information Systems Project. International Journal of Project Management, 17(1), 1-10.

Ibem, E. O. (2010). An Assessment of the Role of Government Agencies in Public-Private Partnerships in Housing Delivery in Nigeria. Journal of construction in developing countries. 15(2), 23-48.

Ibem, E. O., \& Aduwo, E. B. (2012). Public-Private Partnership (PPP) in Housing Provision in Ogun State, Nigeria: Opportunities and Challenges.

Iboh, A. A., Adindu, C. C., \& Oyoh, A. J. (2013). Public Private Partnership Construction Project Disputes in Nigeria. Jorind, 11(1), 6-11.

Li, B., \& Akintoye, A. (2003). An Overview of Public Private Partnership. In A. Akintoye, M. Beck, and C. Hardcastle (Eds.), Public Private Partnerships: Managing Risks and Opportunities. New York: Wiley-Blackwell.

Kargol, A., \& Sokol, E. (2007). Public Private Partnership and Game Theory. Gazdalkodas, 51(19), 93-101.

Marshall, C., \& Rossman, G. B. (1995). Designing Qualitative Research. Newbury Park, CA: SAGE Publications.

Mu, R., De Jong, M., \& Heuvelhof, E. (2010). A typology of Strategic Behaviour During PPP for Expressways: Lessons from China and Implications for Europe. European Journal of Transport and Infrastructure Research, 10(1), 42-62.

National Council For Private Partnership. (2012). Testing Tradition: Assessing the Added value of Public Private Partnerships. Allington, VA 22201: National Council For Private Partnership.

Onuorah, O. B. (2014). Public Private Partnership a Viable Tool for Sustainable Construction in Achieving Quality and Affordable Shelter in Nigeria. The Internal Journal of Science \& Technology. 
Pessoa, A. (2006). Public Private Sector Partnerships in Developing Countries: Prospects and Drawbacks.

Rapoport, A. (1988). Games, Peace and Change. A journal of Peace Research, 13, 1-167

Republic of Ghana. (2011). National Policy on Public Private Partnerships (PPP): Private Participation in Infrastructure and Services for Better Public Service Delievry.

Saunders, M., Lewis P., \& Thornhill, A. (2009).Research Methods for Business Students. Financial Times Prentice Hall Inc., London.

Sengupta, U. (2005). Government Intervention and Public-Private Partnerships in Housing Delivery in Kalkata. Habitat International, 30(3), 448-461.

UN-HABITAT. (2011). Public-Private Partnerships in Housing and Urban Development. The Global Urban Economic Dialogue Series.

Yang, Y., Hou, Y., \& Wang, Y. (2013). On the Development of Public private Paartnerships in Transitional Economies; An Explanatory Framework. The American Society for Public Administration, 73(2), 301-310.

Yin, R. K. (2006). Handbook of complementary methods in education research.American research association. Washington DC.

Zou, W., \& Kumaraswamy, M. (2009). Game Theory Based Understanding of Dynamic Relationships Between Public and Private Sectors in PPPs. In A. Dainty (Ed.), Proceedeings 25th Annual ARCOM Conference (pp. 197-205). Nothingham, UK: Assocition of Reserachers in Construction Management.

\section{Copyright Disclaimer}

Copyright for this article is retained by the author(s), with first publication rights granted to the journal.

This is an open-access article distributed under the terms and conditions of the Creative Commons Attribution license (http://creativecommons.org/licenses/by/3.0/). 